\title{
Het betere werk: inzetten op de kwaliteit van de arbeid
}

\author{
Monique Kremer \& Robert Went ${ }^{*}$
}

Een kleine zes jaar geleden begonnen wij bij de Wetenschappelijke Raad voor het Regeringsbeleid (WRR) aan een onderzoeksproject over de toekomst van werk. In ons rapport Naar een lerende economie (WRR, 2013) werd al gewezen op het belang van werk voor onze economie, en we zagen twee belangrijke ontwikkelingen met potentieel grote gevolgen voor werkende mensen. Daarover gingen we een WRRverkenning maken, over technologisering en flexibilisering. Omdat we in verkenningen, die vaak gebaseerd zijn op bijdragen vanuit verschillende wetenschappelijke disciplines, geen aanbevelingen doen en het kabinet ook niet op een verkenning hoeft te reageren, ${ }^{1}$ voorzag ons projectplan ook in een afsluitend rapport. Het idee was dat we daarin voort zouden bouwen op de analyses in de verkenningen, en aanbevelingen zouden doen. Dat afsluitende rapport, onder de titel Het betere werk. De nieuwe maatschappelijke opdracht, hebben we 15 januari 2020 gepresenteerd en aan minister Koolmees aangeboden in een uitverkocht Pakhuis de Zwijger in Amsterdam. In deze bijdrage gaan we kort in op de ontstaansgeschiedenis en inhoud van het rapport en op het vervolg.

\section{Twee belangrijke ontwikkelingen...}

De eerste verkenning die we maakten ging over robots, artificial intelligence (AI) en automatisering. In 'het tweede machinetijdperk' zijn niet alleen fysieke maar ook sommige mentale taken te automatiseren. Wat zijn daarvan de gevolgen? De verkenning De robot de baas (Went, Kremer \& Knottnerus, 2015), die we 8 december 2015 presenteerden in Pakhuis de Zwijger, kreeg veel aandacht. De korte samenvatting van de analyses in dit boek is: (1) dat het niet zo snel gaat met robots en automatisering als vaak wordt gedacht of geclaimd; (2) dat technologie ons niet overkomt, want overheden, bedrijven, vakbonden en engineers hebben invloed op de ontwikkeling van technologie en technologische toepassingen; en (3) dat we een 'inclusieve robotagenda' moeten ontwikkelen om ervoor te zorgen dat we allemaal beter worden van nieuwe technologie en niet vooral de eigenaars van de robots. We hebben sinds de presentatie pakweg honderdvijftig presentaties en bijeenkomsten over of naar aanleiding van deze verkenning gedaan. Daar hebben we veel van opgestoken waar we in Het betere werk op voort konden bouwen.

* $\quad$ Prof. Monique Kremer is senior wetenschappelijk medewerker bij de WRR. Dr. Robert Went is senior wetenschappelijk medewerker bij de WRR. 
De tweede trend die we analyseerden is de toenemende flexibilisering van werk. De WRR-verkenning Voor de zekerheid. De toekomst van flexibel werkenden en de moderne organisatie van arbeid (Kremer, Went \& Knottnerus, 2017) presenteerden we op 7 februari 2017 in Pakhuis de Zwijger. Ook ditmaal was er veel media-aandacht en volgden er veel presentaties. In deze verkenning combineren we kwantitatieve gegevens met diepte-interviews onder flexibel werkenden. We laten in deze verkenning zien dat de doorgeslagen flexibilisering op onze arbeidsmarkt een gevolg is van nationale politieke keuzes en beslissingen, en geen onontkoombaar gevolg van technologische ontwikkelingen of globalisering. We agenderen in deze verkenning ook voor het eerst dat flexibilisering niet alleen slecht is voor de mensen met een flexbaan (onzekerheid, uitstellen kinderen, geen hypotheek), maar ook voor de economie als geheel (minder innovatie, geen scholing en opleiding voor flexwerkers) en de samenleving (meedoen, erbij horen, de waarde van werk).

\section{...en een derde trend}

Tijdens ons verdere onderzoek voor het eindrapport raakten we er steeds meer van overtuigd dat nog een derde trend van groot belang is voor de toekomst van werk: de intensivering van werk, oftewel de verandering van de snelheid en de aard van het werk. Het is de derde trend die we in dit rapport analyseren, en we hebben daar ook aanvullend onderzoek door laten doen door TNO (Houtman e.a., 2020) en door onderzoekers van de Universiteit van Tilburg (Van den Groenendaal, Van Veldhoven \& Freese, 2020). Intensivering betekent dat mensen meer werk verrichten in minder tijd en vaak met een hogere emotionele belasting. Denk bijvoorbeeld aan de thuiszorgmedewerker, die minder tijd heeft per cliënt, terwijl de mensen waar zij - thuiszorgmedewerkers zijn vooral vrouwen - over de vloer komt veel vaker complexe problemen hebben. Of de leerkracht in het basisonderwijs, die nog steeds hetzelfde aantal uren voor de klas staat, maar er veel taken bij heeft gekregen, zoals administratie, het omgaan met heel veel verschillende kinderen en, niet te vergeten, de steeds mondiger wordende ouders. De intensivering van werk kan een gevolg zijn van de inzet van technologie op de werkplek ('just in time' productie bijvoorbeeld), maar komt ook doordat de economie steeds meer een diensteneconomie is geworden. En het New Public Management speelt eveneens een rol in de publieke sector.

Uit het onderzoek van TNO (Houtman e.a., 2020) blijkt dat inmiddels 38 procent van de werkende mensen zegt vaak of altijd snel te moeten werken om het werk af te krijgen. Vooral in de publieke sector, maar zeker niet alleen daar, is de als te hoog ervaren werkdruk de afgelopen tijd geagendeerd. Leerkrachten, universiteitsmedewerkers en zorgprofessionals trokken naar het Malieveld. Eén op de tien werkenden ervaart een hoge emotionele belasting. Intensivering kan ook meer mensen uit de arbeidsmarkt drukken die niet kunnen voldoen aan de hoogproductieve eisen, bijvoorbeeld als zij een (mentale) arbeidsbeperking hebben. En het kan de re-integratie van mensen met kanker of een burn-out ingewikkelder 
maken. Meer autonomie op het werk, zo blijkt uit al het onderzoek, is een buffer tegen intensivering

\section{Naar de kwaliteit van werk}

Het perspectief dat we in Het betere werk bieden op de toekomst van werk is breder en dieper dan de kwantitatieve benadering die veel berichtgeving en discussies over werk (en over de gevolgen van technologie) domineert. Het gaat vaak over hoeveel werk er is - 'werk, werk, werk' -, maar veel te weinig over wat de kwaliteit van dat werk is. Maar technologisering, flexibilisering en intensivering zijn niet alleen medebepalend voor de hoeveelheid werk en voor wie werkt, maar vooral ook voor de kwaliteit van werk. Daar is volgens de WRR nog te weinig aandacht voor, en dat - 'goed werk, goed werk, goed werk' - willen we met dit rapport agenderen. Want werk is goed voor het inkomen en het zelfrespect van individuen, en voor de samenleving. Maar dat geldt vooral als dat werk goed is.

\section{Goed werk is grip hebben}

Maar wat is eigenlijk goed werk? Uit economische, sociologische en psychologische wetenschappelijke literatuur distilleren we drie belangrijke condities voor goed werk die goed passen bij de aard van de Nederlandse kennis- en diensteneconomie en bij de wensen en verwachtingen van mensen in de samenleving (zie ook Conen, 2020):

1 Grip op geld. Goed werk is werk dat voldoende (financiële) zekerheid oplevert, ook in verhouding tot anderen en op de lange termijn.

2 Grip op het werk. Goed werk is werk met gepaste autonomie, waarin een beroep wordt gedaan op je capaciteiten, en goede sociale relaties worden onderhouden.

3 Grip op het leven. Goed werk is werk met voldoende tijd en mogelijkheden voor het combineren van werk met zorgtaken en een privéleven.

Deze condities zijn alle drie noodzakelijk voor goed werk. Als er niet aan voldaan wordt, is dat nadelig voor werkenden en arbeidsorganisaties, en kan dat ook leiden tot hogere maatschappelijke kosten. Goed werk vergroot het welzijn en de gezondheid van mensen en hun betrokkenheid, en dat draagt bij aan de productiviteit en goed functionerende, innovatieve arbeidsorganisaties. Goed werk helpt ook om mensen langer te laten doorwerken en om de kosten van de gezondheidszorg te beperken. Daarnaast is goed werk voor iedereen ook beter voor de sociale samenhang. Mensen zijn dan beter in staat relaties aan te gaan en zich te verbinden met de samenleving als geheel. Voor de sociale samenhang is het dus het beste als iedereen goed werk heeft. 


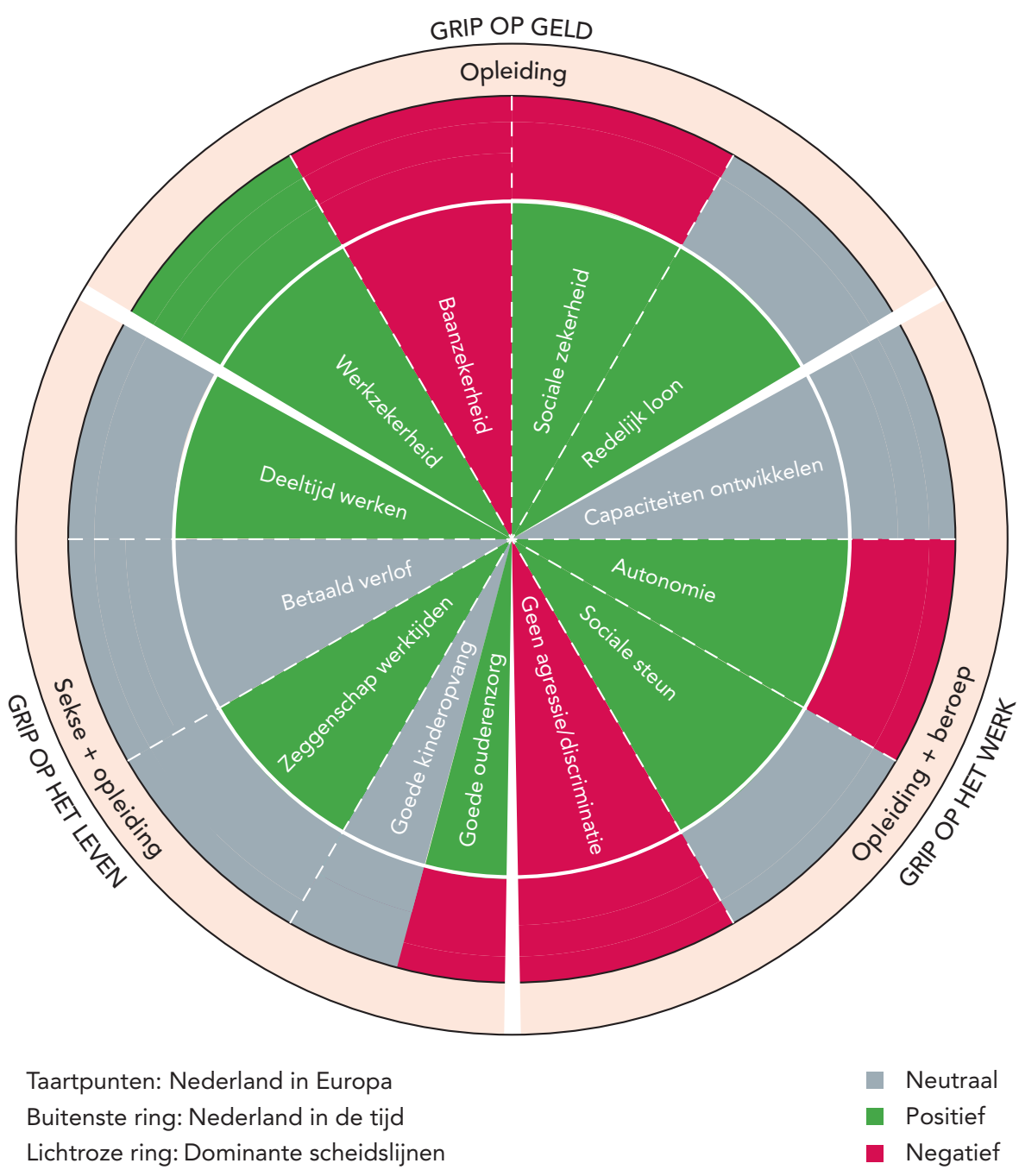

Bron: WRR, geïnspireerd door de Monitor Brede Welvaart (CBS)

Figuur 1 Kwaliteit van werk in Nederland, in Europa, in de tijd, 12 indicatoren

\section{De kwaliteit van werk kan beter in Nederland}

Als we de drie condities van het goede werk samennemen, dan loopt Nederland niet voorop in Europa. In recent onderzoek van de Organisation for Economic Cooperation and Development (OECD, 2016) en Eurofound (2017) staat ons land niet bovenaan, maar zijn we vaker te vinden in de middenmoot. Dat kan en moet beter, vindt de WRR. 


\section{Meer grip op geld}

Hoewel er nog nooit zoveel banen zijn gecreëerd in ons land, zijn dat vooral flexibele banen. In vergelijking tot andere Europese landen werken lageropgeleiden in ons land wel, maar vaak is dat onzeker werk. In 2008 was 34 procent van de lageropgeleiden zzp'er of had een tijdelijk contract, maar in 2018 was dat 45 procent. Daar zitten grote nadelen aan. Het innovatieve vermogen van arbeidsorganisaties kan er negatief door beïnvloed worden: wie een tijdelijk contract heeft, zal minder snel kritiek leveren of ideeën aandragen om het werk te verbeteren. Breder in de samenleving zijn er ook negatieve gevolgen: mensen met flexibele contracten stellen hun kinderwens uit. De Duitse minister van Gezinszaken zei dat de flexibele arbeidsmarkt de beste vorm van anticonceptie is. De mogelijkheden om te leren en te ontwikkelen op het werk nemen bovendien niet toe, vooral niet voor mensen met een flexibel contract. Werkgevers investeren het minst in hen.

Sociale zekerheid, ook belangrijk voor de kwaliteit van werk, is een bron van onzekerheid geworden voor veel werkenden. Vooral voor zzp'ers, die geen recht hebben op sociale verzekeringen, maar ook geen plicht tot het betalen van premies. Dit betekent dat zij nauwelijks verzekerd zijn tegen 'oude risico's' zoals arbeidsongeschiktheid en ouderdom, en evenmin tegen 'nieuwe risico's' zoals zorgverantwoordelijkheden of voldoende scholing. Bovendien dragen zij financieel weinig bij aan het collectieve socialezekerheidsstelsel. Het is daarom nodig om een meer op de moderne arbeidsmarkt toegesneden stelsel van sociale zekerheid te ontwikkelen waarin ook alle zzp'ers deelnemen.

Ongeveer 1 miljoen mensen in ons land willen en kunnen werken, maar doen dat nu niet of willen meer uren werken (in 2019). Ook hebben 1,6 miljoen mensen een uitkering (in 2017). Een deel van hen is langdurig werkloos - in Nederland is dat deel groter dan elders in Europa - en heeft daarbij complexe problemen. En een aanzienlijk deel van mensen met een arbeidsbeperking staat buiten de arbeidsmarkt (60 procent) - dat percentage is de laatste jaren zelfs toegenomen. Tegelijkertijd wordt nauwelijks meer geïnvesteerd in actief arbeidsmarktbeleid, zeker als we dat vergelijken met andere landen in Europa. Mensen zonder werk krijgen nauwelijks scholing of persoonlijke begeleiding. En dat terwijl het hebben van werk zo belangrijk is voor de gezondheid en het welbevinden van mensen, en voor de sociale samenhang in ons land. Als werk psychologisch en sociaal zo belangrijk is, kunnen we mensen niet 'afschepen' met een uitkering. Het sluitstuk van de sociale zekerheid zou dan ook niet de bijstand moeten zijn, maar een basisbaan.

\section{Aanbevelingen}

\section{Grip op geld}

1 Voorkom oneerlijke concurrentie tussen werkenden met verschillende contractvormen. 
2 Ontwikkel een stelsel van contractneutrale basisverzekeringen en voorzieningen voor alle burgers dat past bij de nieuwe wereld van werk.

3 Vernieuw het actieve arbeidsmarktbeleid, onder andere door meer aandacht voor persoonlijke begeleiding.

4 Geef personen met een uitkering en weinig kans op de arbeidsmarkt een basisbaan.

\section{Meer grip op het werk}

Als we kijken naar grip op het werk, de tweede conditie van goed werk, zien we dat bijna de helft van de werkenden in ons land een gebrek aan autonomie op het werk ervaart. Bedrijven en instellingen halen niet altijd het beste in mensen naar boven. Hoewel veel werkenden sociale steun ervaren op het werk, scoort Nederland tegelijkertijd hoog - ook in vergelijkend perspectief - als het gaat om agressie op de werkvloer. Te weinig grip op het werk houdt deels verband met een toenemend aantal mensen met burn-outklachten (17 procent in 2018), en bijna de helft van alle verzuimdagen in Nederland houdt verband met het werk zelf. Het Rijksinstituut voor Volksgezondheid en Milieu (RIVM) schat dat ongunstige arbeidsomstandigheden in ons land ongeveer 5 procent van de totale ziektelast veroorzaken; dat is vergelijkbaar met de lasten van overgewicht (zie Van Echtelt, 2020).

Vakbonden en werkgevers zouden hun aandacht vaker mogen richten op de werkplek zelf. Dat is een wederzijds belang. De Vlaamse SERV heeft daar in Vlaanderen het voortouw voor genomen door de kwaliteit van werk te monitoren en als doel van beleid te maken. Elke vier jaar wordt daar de 'werkbaarheidsindex' berekend, die richtinggevend is voor nieuwe beleidsafspraken. Op basis van discussies hierover hebben de sociale partners en de overheid in december 2018 overeenstemming bereikt over een actieplan. Kern van dit plan is de 'innovatieve arbeidsorganisatie', wat we in Nederland 'sociale innovatie' zouden noemen. Dat is een voorbeeld dat navolging verdient.

De Finse overheid, een ander voorbeeld, heeft het verbeteren van de kwaliteit van arbeid in hoofdletters in beleidsnotities gezet. Het betere werk komt - door marktfalen, managementstijlen, gebrek aan informatie, onvoldoende kennis, een tekort aan middelen - niet altijd en overal vanzelf tot stand. Omdat het gaat om maatschappelijke belangen - brede welvaart, productiviteit -, heeft de overheid een rol om hier met harde en zachte regulering bij te helpen. Onze overheid kan zich inzetten voor een programmatische aanpak om goed werk voor meer mensen te bevorderen. Gedacht kan worden aan allerlei vormen van 'zachte regulering': campagnes, algemene doelen en normen; kaders en aanbevelingen; informatie over best practices; managers en werknemers trainen en opleiden; advies toegankelijk maken voor werkgevers en werknemers; benchmarking; bindende vooralsnog vrijwillige - afspraken; subsidies voor bedrijven om deskundigheid in te huren (bijvoorbeeld innovatievouchers), enzovoort. De overheid en sociale 
partners zouden ook kunnen bevorderen dat bedrijven en instellingen jaarlijks rapporteren over de (ontwikkeling van de) kwaliteit van het werk dat zij bieden.

\section{Grip op het werk}

- 5. Ontwikkel een programmatische aanpak voor goed werk binnen bedrijven en instellingen.

- 6 . Versterk de positie van werkenden binnen arbeidsorganisaties.

\section{Meer grip op het leven}

Over de derde conditie van goed werk - grip op het leven - zegt één op de tien werkenden in ons land al geruime tijd dat er een disbalans is tussen thuis en het werk (Houtman e.a., 2020). Grip op het leven wordt in ons land vooral georganiseerd door in deeltijd te gaan werken. Er is sprake van een 'deeltijdklem', volgens econoom Plantenga (2017). De kosten daarvan komen op korte termijn voor rekening van het individu, vooral vrouwen, en op de langere termijn voor de samenleving. Nederland excelleert niet met kwalitatief hoogstaande kinderopvang, en ouderenzorg is niet toegerust voor werkende mantelzorgers. Ons land heeft vergeleken met andere Europese landen door het 'deeltijdideaal' zeer beperkte betaalde verlofregelingen voor de zorg voor kinderen en ouderen. En lang niet iedereen (slechts de helft van de werkenden) heeft voldoende zeggenschap over de eigen werktijden om grip te hebben op het leven.

\section{Grip op het leven}

- 7. Schep meer mogelijkheden om mensen de keus te laten hoeveel uren ze willen werken, onder andere door goede kinderopvang en ouderenzorg te bieden en meer werken makkelijker afdwingbaar te maken.

- 8. Zorg voor langdurige, collectief betaalde verlofregelingen voor zorg en meer zeggenschap over arbeidstijden.

\section{Het betere werk is een zaak voor iedereen}

Om de ontwikkeling van het betere werk op de agenda te houden zouden de drie condities van goed werk - grip op geld, grip op het werk en grip op het leven - en de verdeling daarvan over de bevolking een plaats moeten krijgen in de Monitor Brede Welvaart, die sinds 2018 elk jaar op Verantwoordingsdag wordt gepubliceerd (zie figuur 1). Dat kan eraan bijdragen dat het betere werk de aandacht krijgt van beleidsmakers en betrokkenen die het verdient.

\section{Goed werk}

- 9. Maak de drie condities van goed werk en de verdeling daarvan over de bevolking basis van overheidsbeleid en volg deze in de Monitor Brede Welvaart. 


\section{En nu?}

We willen met ons rapport de kwaliteit van arbeid agenderen als een cruciaal thema waar de overheid, werkgevers, werknemers en sociale partners nog veel te weinig aandacht voor hebben. Dat is deels al gelukt, blijkt uit de reacties in de media, uit de vele verzoeken voor presentaties die binnenkomen - van sociale partners tot gemeenten en beroepsorganisaties - en uit het plenaire debat dat op 5 februari in de Tweede Kamer gevoerd is over het rapport van de commissieBorstlap en ons rapport. ${ }^{2}$

Er volgt nog een officiële kabinetsreactie, die ongetwijfeld opnieuw tot discussie zal leiden, maar een van onze aanbevelingen is al overgenomen door minister Koolmees. Op verzoek van enkele Kamerfracties gaat hij aan het CBS vragen om de kwaliteit van werk - grip op geld, grip op het werk en grip op het leven - op te nemen in de Monitor Brede Welvaart die elk jaar gemaakt wordt. Het betere werk zal zo in de aandacht blijven, maar daarmee zijn we er natuurlijk niet. We hopen en rekenen - op de inzet en betrokkenheid van werkenden, werkgevers, de SER, koepels en sector- en brancheorganisaties, onderzoekers en - last but not least overheden voor goed werk voor iedereen die wil en kan werken.

\section{Noten}

1 Dat gebeurt in de praktijk overigens meestal wel, bijvoorbeeld omdat de Kamer om een reactie vraagt.

2 Zie www.tweedekamer.nl/kamerstukken/plenaire_verslagen/kamer_in_het_kort/ kamer-spreekt-over-de-toekomst-van-werk.

\section{Literatuur}

Coates, D. (2009). Advancing Opportunity: The Future of Good Work. Londen: The Smith Institute.

Conen, W. (2020). Waarde van werk in Nederland (WRR working paper 38). Den Haag: Wetenschappelijke Raad voor het Regeringsbeleid.

Echtelt, P. van (2020). Werk, zaligmakend of ziekmakend? De relatie tussen arbeid en gezondheid (WRR working paper 39). Den Haag: Wetenschappelijke Raad voor het Regeringsbeleid.

Eurofound (2017). Sixth European Working Conditions Survey - Overview Report. Luxemburg: Publications Office of the European Union.

Frey, C., \& Osborne, M. (2013). The Future of Employment: How Susceptible are Jobs to Computerisation? Oxford: Oxford Martin Programme on Technology \& Employment.

Groenendaal, S.M. van den, Veldhoven, M. van, \& Freese, Ch.(2020). Werkintensivering van beroepen (WRR working paper 37). Den Haag: Wetenschappelijke Raad voor het Regeringsbeleid.

Houtman, I., Dhondt, S., Kraan, K., \& Vroome, E. de (2020). Intensivering van werk in Nederland: wat is het, waar staan we en wat te doen? (WRR working paper 36). Den Haag: Wetenschappelijke Raad voor het Regeringsbeleid. 
Kremer, M., Went, R., \& Knottnerus, A. (red.) (2017). Voor de zekerheid. De toekomst van flexibel werkenden en de moderne organisatie van arbeid. Den Haag: Wetenschappelijke Raad voor het Regeringsbeleid.

Nedelkosta, L., \& Quintini, G. (2018). Automation, Skills Use and Training (OECD working paper). Beschikbaar via http://pmb.cereq.fr/doc_num.php?explnum_id=4268.

OECD (2016). How Good Is Your Job? Measuring and Assessing Job Quality. Parijs: OECD.

Plantenga, J. (2017). Flexibel werken en de combineerbaarheid van werk en zorg. In: M. Kremer, R. Went \& A. Knottnerus (red.), Voor de zekerheid. De toekomst van flexibel werkenden en de moderne organisatie van arbeid. Den Haag: Wetenschappelijke Raad voor het Regeringsbeleid, 257-273.

Went, R., Kremer, M., \& Knottnerus, A. (red.) (2015). De robot de baas. De toekomst van werk in het tweede machinetijdperk. Amsterdam: AUP.

WRR (2013). Naar een lerende economie. Investeren in het verdienvermogen van Nederland. Amsterdam: AUP. 